\title{
A história da química como ferramenta para ensino de cinética química
}

\section{Vitor dos Santos Ferreira (UEMG/Câmpus Ubá)}

\section{RESUMO - PÔSTER}

O melhor entendimento dos conceitos químicos e o interesse pela disciplina são alguns dos desafios que envolvem o ensino de química. $O$ uso do contexto histórico no ensino pode ser útil, pois promove a melhor compreensão dos conceitos, pode neutralizar o cientificismo que a disciplina carrega e trazer os problemas e soluções que os cientistas enfrentaram. Nesse trabalho foram realizadas três pesquisas com 0 intuito de avaliar o que graduandos do $8^{\circ}$ período do curso de licenciatura em Química, professores de Química do Ensino Médio e estudantes de uma turma do $2^{\circ}$ ano do Ensino Médio de uma escola pública em Ubá-MG pensam sobre o uso da História da Química como ferramenta didática para 0 ensino. Com os estudantes do $2^{\circ}$ ano, além do questionário foi aplicada uma aula prática com contexto histórico sobre Cinética Química. A análise dos resultados revelou as concepções favoráveis que graduandos e professores possuem sobre a História da Química, apesar dos professores não se sentirem preparados para usá-la. Os estudantes participantes da pesquisa demonstraram entender melhor os conceitos que envolvem a cinética química e segundo eles, o contexto histórico que envolve a prática deixou a aula mais interessante. 